\title{
Bitter Milk: Women and Teaching by Madeleine
}

R. Grumet, Amherst: University of Massachusetts

Press, 1988

Reviewed by

Wendy Soderberg

\section{Gloria Toole}

\section{Pat Kover \\ University of Calgary}

\section{Drinking "Bitter Milk"}

Wherein Every Attempt to Reconstruct Meaning Leads to a New and Different Meaning

In Sri Lanka girls who suffer a psychotic response to the turmoil of adolescence, to the conflicting emotions occasioned by the separation from family, are given a ritual tonic made from milk and crushed margosa leaves, that same "bitter milk" which mothers spread on their nipples to wean babies. For Grumet, this "bitter milk, fluid of contradictions: love and rejection, sustenance and abstinence, nurturance and denial" (p. xi) becomes a metaphor for the relationship between women and teaching. For it has fallen to female elementary teachers to lead children from the feminine, connected world of the home where knowledge evolves in experience and relationships into the masculine world of the school where such knowing and connectedness have traditionally been treated with contempt. It is women who have been charged with the responsibility of leading the child into this world where women's experience is denied and denigrated. Bitter Milk is an attempt to reclaim, in education and ultimately in life, a middle ground where both men's and women's ways of knowing would be at once honored and valued.

In designating the private world of nurturance and connectedness as the woman's domain and the public world of objectivity, production, and achievement as the man's sphere, Grumet is aware that these designations contradict the experience of many of us whose fathers also nurtured, whose mothers went forth as speakers in the forum. Indeed, Grumet's passionate conviction that there is a middle ground arises out of her experience that in our personal relationships we do find "a mediat- 
ing space, a place where we can heal" (p. xvi). Grumet speaks out of a fundamental belief that knowledge evolves in human relationships. Yet school has remained, for the most part, a place where any personal consideration has been rigorously excluded from the realm of knowledge, and where the very hallmark of scholarship has been the ability to abstract not only the knower from the known, but also the known from the very living experience out of which it evolved.

Grumet suggests that our valuing of this kind of knowledge can be traced to the evolution of distinct masculine and feminine epistemologies. These arise from the differing natures of maternity and paternity and of their interaction with the need of the child to establish itself as an independent being. The bond between mother and child is close, immediate, and undeniable. Beginning as an actual physical bond, it remains even after birth one of close attachment and interdependence: The rhythms of the mother's day are a response to the needs of the child. The nature of paternity is much less direct: separate where that with the mother is connected. In those early days when mother and child constitute a mutually interdependent subject, the father stands as object, his relationship with the child mediated by the mother. In compensation of this distance from the child, paternity has tended to deny the importance of those qualities that characterize the mother-child relationship. The father, moving into that public world where the means of production are centered, is removed also from what Grumet refers to as the "tasks and pleasures of nurturance." These tasks then become seen as the work of the mother, who, isolated in the private world, loses her "productive role" but has increasing responsibility for the moral, social, and emotional development of children.

But the growing child's need to become independent expresses itself increasingly in the need to separate from the mother and to identify with the father who, for daughters as well as sons, represents an escape from the threat of being enveloped by the mother. But where the son to become independent must break away from the female bond and make identification with the father and with all that is separate from the mother, connectedness, the daughter, on the other hand, has no such need. Identifying with the father offers the girl an escape from the threat of being subsumed into the mother-child relationship, but it does not require her to suppress her connectedness. As Grumet puts it: "for her, external objectivity becomes an alternative postoedipal object relation rather than a substitute for the pow- 
erful and emotional experiences of early childhood, which she retains as well" (p. 13).

It is in this movement of women to establish their independence by identification with that separate world represented by the father that we find the reason why women, who are the majority of our teachers, leave their roles and their identities as nurturers in a family to become "agents who deliver their children to the patriarchy" (p. 32). To understand this process, Grumet first asks us to return to the United States of the 19th century, to the foundations of the industrial revolution in that country. Farming families moved to the cities where the men went to factory jobs while the women remained at home with their children. The middle-class leaders of the country identified a new problem. How were these uprooted families to be controlled and integrated into this new environment and economic arrangement? How was their identity with the nation to be forged? The state school system was introduced. This system needed to run smoothly and inexpensively. The educated middle class was scoured for teaching recruits. But for middle-class men on their way to better paying professional jobs, teaching was only a whistle stop. Middle-class single women, on the other hand, had few employment opportunities. So they were hired by supervisors of state education. Appealing to their sense of feminine sacrifice, and exploiting their accepted low economic and social position, these women were then used as vehicles to transfer the ideas and values of a public and male world.

It is not that Grumet calls for a repudiation of this independent male world in favor of the female world of nurturing and dependence. Rather, she urges a middle ground in the schools that melds the features of nurturance and dependence together with patriarachy and independence. Curriculum, according to this view, becomes a moving point constructed through such reciprocity.

To understand the kind of curriculum evolving through Bitter Milk, let us consider, for example, how we might approach the printed text in a literature class. Grumet, like most of us, was raised to believe that the text held a single meaning and that our duty as scholars was to unbolt the printlocked concept hidden behind the words. In Grumet's classroom, however, textual meaning becomes a socially collaborated understanding, developed through discussion between teacher and student as they explore their associations and thoughts about the texts. "A curriculum designed for my child is a conversation that leaves space for her responses, that is transformed by her questions. It needn't replicate her language or mine, but it must be made 
accessible" (p. 173). Little can be fixed or predetermined in a classroom like Grumet's.

Grumet believes that freedom is gained through knowledgeable choices that have been lived in context. While curriculum is a moving point, power comes partly through access to our past. Continuity is necessary here. Parents hold the continuities of the lives of their children: They are aware of the lost selves and the discontinued themes because they have lived intimately with their children over time. Teachers have not done that. So if we, as teachers, are to offer the greatest freedom of choice to our students, we need to work reciprocally with our children and their parents, particularly their mothers who are the clearest representatives of their intimate worlds.

It is in this intimate world that Grumet finds her starting point. From it come the learners, the children whom education must prepare to redeem the world, and the mother/teachers who leave nurturance outside the classroom door and thus allow themselves to be estranged from both the teachers of their children and the mothers of their students. All are raised in a social milieu that is unbalanced, that systematically denies the value of experience that is personal and nurturing in favor of that which is impersonal and abstract. It is Grumet's contention that, in allowing this separation of knowledge from its roots in connected relationships, we make possible that deafness to human suffering that allows us to ignore social injustice and, ultimately, to inflict on ourselves and others the obscenity we call war.

In schools we become civilized by denying attachment ... But the same guise of neutrality that permits the meritocracy to flourish can also function to rationalize the most arbitrary and violent self-interest. It is the kind of dehumanized thinking that finds its ultimate terror in an Adolph Eichmann, who reported that he held no personal antagonism for the Jewish people, but was merely effecting the solution to a "political problem." (p. 181)

The role of female teachers is thus to reclaim their experience of nurturing and their deep understanding of how knowledge evolves from relationships, not only to do something about what lies behind the closed doors of their classrooms, but also to affect the wide public forum where more sanguine voices sorely need to be heard.

But if knowledge is so intimately connected, what is the place of subject matter? Does it leave the teacher with nothing to teach? On the contrary, part of the knowledge that the teacher brings to the situation is knowledge of the subject, but what she 
teaches and how she teaches it are always open to the affect and the effect of the responses given by the daughter in that conversation called curriculum. Although Grumet views the role of teacher from a new perspective, her teacher is responsible in both masculinist and feminist senses of the word. She is both the one who accepts the charge and takes upon herself the requirement to respond, and the one who is response-able, which is to say, sensitive to and willing to accommodate the needs of others.

Bitter Milk might be considered a personal-theoretical articulation of the author's own experience. Certainly Grumet's argument that society is strongly split between the masculine and feminine worlds is based on psychological, Marxist, and feminist theory. However, woven into this theoretical base throughout the book are both glimpses of her own personal experience and her argument for the necessity of the reintegration of the masculine and feminine into what she calls the middle ground. She feels that children move from the predominantly holistic world of the home and family to the segregated or separated experiences of the average school day. Grumet strongly believes that this dichotomy that exists in a child's life need not occur if schools were able to modify classroom practice by integrating masculine and feminine into a middle ground.

Grumet speaks directly to women in the teaching profession, and particularly to those "women who think back through their mothers" (p. 192). She would like to see women unite in taking the initiative to help create a bridge between private and public worlds. With the establishment of this middle ground, she believes that the dichotomies of "internal and external, dream and reality, body and thought, poetry and science, ambiguity and certainty" would diminish. In order for this blending of two separate worlds to occur, however, there must be mediation of the oppositions of home and work place, supported by the economic, religious, and legal systems.

Grumet believes that this is essential in order to reconnect our private and public worlds so that we will be able to experience the "most loving and creative expressions of masculinity and femininity" (p. xix).

I know that, although this is a book about women, it is also a book about men. I know that when it celebrates the presence and affection of my mother, my daughters, and my friends I am also celebrating the care and commitments of my father, my husband, my son and many of the men who are wonderful teachers and with whom I am proud to share my work. (p. xix) 
It is precisely this concept of the middle ground that makes Grumet's vision so attractive, for it allows us to resolve the contradictions posed by the presence in our private worlds of men who are caring and nurturing and in our public worlds of women who are active and energetic. By bringing into the public world the realization that knowledge evolves in human relationships, by bringing our whole selves to our knowing, we may find a place, that middle ground, where not only we but also society may heal. 